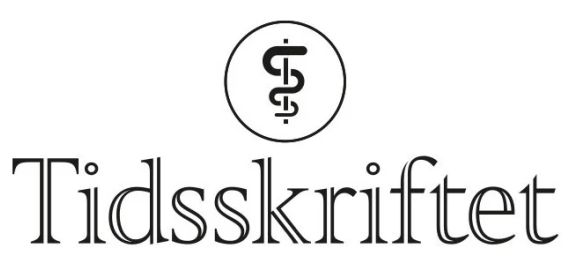

DEN NORSKE LEGEFORENING

\title{
Profylaktisk behandling etter varicellaeksponering
}

OVERSIKTSARTIKKEL

\section{JEANETTE SCHULTZ JOHANSEN}

Jeanette Schultz Johansen (f. 1980)

er cand.pharm. og Rådgiver ved RELIS Sør- $\emptyset$ st og Avdeling for smittevern Oslo Universitetssykehus. Ingen oppgitte interessekonflikter.

Email: jeajoh@ous-hf.no

Regionalt legemiddelinformasjonssenter (RELIS Sør- $\emptyset \mathrm{st}$ )

\section{TONE WESTERGREN}

Tone Westergren (f. 1959)

er cand.pharm./spesialist i sykehusfarmasi. Hun er seksjonsleder for RELIS Sør-Øst, Avdeling for farmakologi, Oslo universitetssykehus.

Ingen oppgitte interessekonflikter.

Regionalt legemiddelinformasjonssenter (RELIS Sør-Øst)

\section{EGIL LINGAAS}

Egil Lingaas (f. 1950)

er avdelingsleder ved Avdeling for smittevern ved Oslo universitetssykehus. Han er dr.med., spesialist i medisinsk mikrobiologi, og har arbeidet med forebygging av infeksjoner i helsetjenesten.

Ingen oppgitte interessekonflikter.

Avdeling for smittevern

Oslo universitetssykehus, Rikshospitalet

\section{BAKGRUNN}

. Varicella (vannkopper) kan ha alvorlig og noen ganger fatalt forløp, spesielt hos immunkompromitterte personer. Det kan være behov for profylakse mot varicella til noen grupper av eksponerte pasienter. Vi har undersøkt hvilken dokumentasjon som foreligger for profylaktiske tiltak etter eksponering for varicella-zoster-virus.

\section{MATERIALE OG METODE.}

Artikkelen er basert på et ikke-systematisk litteratursøk i Medline, The Cochrane Library, UpToDate og Clinical Evidence.

\section{RESULTATER.}

Det er lite og svak dokumentasjon for at profylaktiske tiltak etter eksponering for varicella-zostervirus reduserer risiko for utvikling av varicella og sykdommens alvorlighetsgrad. Det er noe dokumentasjon for at passiv immunisering med varicella-zoster-immunglobulin (VZIG) innen 7296 timer etter eksponering reduserer risiko for alvorlig forløp av varicellainfeksjon. Profylaktisk aciklovir har vist bedre effekt på sykdomsrate enn kontroll i flere studier, i hovedsak med friske barn, men studiene er små og har varierende kvalitet. Vaksinasjon etter eksponering er vist å redusere sykdomsrate og alvorlighetsgrad av varicella hos friske barn. 
. Basert på den begrensede informasjon som foreligger, mener vi at aciklovir eller valaciklovir har en plass som profylakse hos risikopasienter hvor VZIG er indisert, men ikke gitt eller administrert for sent.

Varicella (vannkopper) er forårsaket av primærinfeksjon med varicella-zoster-virus. Hos friske personer er det vanligvis en mild, forbigående sykdom. Hos enkelte pasientgrupper, som immunkompromitterte pasienter, gravide, premature og nyfødte barn av mødre som får varicella perinatalt, er det økt risiko for å utvikle alvorlig og noen ganger fatalt forløp (1).

Varicella har en inkubasjonstid på cirka 15 dager (variasjonsbredde 10-21 dager) $(\underline{1}, \underline{2})$. Dette tidsintervallet kan gi rom for tiltak som kan hindre eller svekke utviklingen av klinisk sykdom (2 $)$. Pasienter er mest smittsomme 1-2 dager før og kort tid etter utvikling av utslett. Viruset kan overføres til alle blemmene har fătt skorper, typisk 4-7 dager etter at utslett har brutt ut (1).

Risikoen for smitte vil variere med lengden og typen av eksponering. Risikoen er størst for personer i samme husstand. Her smitter varicella og disseminert herpes zoster i cirka $85 \%$ (spredning 65-100\%) av tilfellene (1). Risikoen for smitte etter sykehuseksponering (deling av rom eller direkte kontakt med infisert person) er antatt å være cirka $20 \%$ av risikoen ved smitte i husstand (1). Hvor lang direkte innendørs kontakt (ansikt til ansikt) bør være for at det kan regnes som en signifikant eksponering er ikke fastslått, men kontakten må være mer enn forbigående. Anbefalinger spriker fra over fem minutter til over en time (1). Lokalisert herpes zoster kan også smitte og gi primærinfeksjon med varicella, men er langt mindre smittsomt enn disseminert herpes zoster og varicella (1).

Det kan være aktuelt å igangsette profylakse etter en signifikant eksponering for varicella-zostervirus hos pasienter som har økt risiko for alvorlig sykdom og død av varicella, og som ikke har antistoffer fra tidligere infeksjon eller fra mor. Immunkompromitterte er den største gruppen og inkluderer pasienter under immunsuppressiv behandling, samt pasienter som har sykdommer og tilstander som gir redusert immunforsvar. Ved beinmargstransplantasjon regnes pasienten som ikke-immun uavhengig av tidligere varicella (1) .

Alternativene for profylakse er passiv immunisering med immunglobulin, aktiv immunisering med vaksine, og antiviral profylakse, eventuelt kombinasjoner av disse. Målet med artikkelen er å gi en vurdering av dokumentasjonen for de ulike profylaksealternativene.

\section{Materiale og metode}

Artikkelen er basert på ikke-systematisk litteratursøk i Medline, The Cochrane Library database, UpToDate og Clinical Evidence, med et skjønnsmessig utvalg av artikler basert på forfatternes erfaring innen kildevurdering og smittevern.

\section{Passiv immunisering}

Det benyttes ulike betegnelser på varicella-zoster-immunglobulin i litteraturen. Immunglobulin fra plasmadonorer utvalgt på grunn av høyt antistofftiter mot varicella-zoster-virus kalles VZIG, mens immunglobulin fra pasienter etter herpes zoster kalles zosterimmunglobulin (ZIG). Immunisering med VZIG eller ZIG er antatt å redusere utviklingen av klinisk sykdom, gi mildere sykdom og lavere komplikasjonsrate $(\mathbf{1}, \underline{2})$. Effekten av VZIG og ZIG er vist å være lik $(3,4$.). Immunkompromitterte pasienter som behandles med VZIG får mildere sykdom enn historiske kontroller fra tiden før VZIG var tilgjengelig (1). Disse observasjonene har gjort at placebokontrollerte studier av VZIG ikke har latt seg gjennomføre hos immunkompromitterte pasienter av etiske grunner (5). I to studier med immunkompromitterte barn fant man at 36-44\% av pasientene utviklet klinisk varicella etter eksponering av søsken/foreldre på tross av profylakse med VZIG/ZIG (44.5). I en randomisert, kontrollert studie ble 12 friske barn, seks søskenpar, eksponert for familiemedlemmer med varicella. Søsknene ble randomisert til enten ZIGprofylakse eller samme mengde vanlig humant immunglobulin. Ingen av de seks som fikk ZIGprofylakse innen 72 timer utviklet varicella, mot seks av seks som fikk profylakse med humant immunglobulin (므). 
Hos barn av mødre som får vannkopper perinatalt er det ikke vist at VZIG til barnet reduserer risikoen for klinisk varicella (1), men de som blir syke får gjerne mild sykdom, mot en tidligere beskrevet dødelighet på 31 \% (7.). Det er imidlertid beskrevet alvorlige infeksjoner og død hos nyfødte selv etter profylakse med VZIG $(7, \underline{8})$.

Pasientgrupper hvor VZIG er indisert i Norge er oppsummert i ramme 1. I andre land blir VZIG anbefalt til eksponerte ikke-immune gravide, men dette er ikke vanlig i Norge $(9, \underline{10})$. VZIG gitt til den gravide forebygger ikke infeksjoner hos fosteret, men kan muligens redusere risiko for alvorlig varicella hos mor (1). Det kan være forskjell på antistofftiter mellom ulike produsenters VZIG og mellom ulike produksjonspartier (batch). Doseringsanbefalingen som medfølger produktet bør følges (므). I Norge kan VZIG skaffes på spesielt godkjenningsfritak (9.). Når VZIG er indisert, må det gis så raskt som mulig. Vi har ikke funnet studier der man har undersøkt hvor lang tid etter eksponering man kan forvente effekt av VZIG, men det er vanlig å anbefale at det gis innen de første 72-96 timene $(\underline{1}, 9$.$) .$

\section{Ramme 1}

\section{Pasienter hvor varicella-zoster-immunglobulin (VZIG) er indisert, omarbeidet etter}

(9)

- Nyfødt barn av seronegativ mor hvis mor får utbrudd av varicella nær fødselen eller barnet eksponeres inntil en uke etter fødselen. Risikoen for alvorlig sykdom er størst hvis mor får utbrudd mellom 4 dager før og 2 dager etter fødselen.

- Premature barn som utsettes for varicella-zoster smitte før hjemreise fra sykehus, uavhengig av om mor har hatt varicella.

- Seronegative personer med grunnsykdom som gir risiko for livstruende forløp av varicella. Den viktigste gruppen er personer med medfødt eller ervervet immunsvikttilstand, inkludert medikamentell immunsuppresjon.

Varigheten av beskyttelsen etter en injeksjon med VZIG er ukjent, men man antar den varer i alle fall en halveringstid, som er cirka tre uker (1). Folkehelseinstituttet angir en beskyttelsestid på cirka seks uker (9.). Selv om man gir VZIG, vil som nevnt en del av pasientene likevel utvikle varicella. Inkubasjonstiden kan være forlenget etter VZIG-terapi. Pasienten bør monitoreres for symptomer og tegn på varicella i 28 dager etter eksponering (11). Ved tegn på klinisk varicella må man raskt sette i gang antiviral behandling, helst innen 24 timer etter start av utslett, dette for ytterligere å redusere risikoen for alvorlig sykdom (1ㅡ). Siden subkliniske infeksjoner forekommer, bør immunstatus kontrolleres etter cirka to måneder (프).

VZIG er kostbart og kan være vanskelig å skaffe. Vanlig immunglobulin for intravenøs infusjon (IVIG) kan være et alternativ (므). Mengden varicella-zoster-antistoff varierer mellom IVIGpreparatene (ㅁ). Pasienter som får månedlig høydose IVIG ( $\geq 400 \mathrm{mg} / \mathrm{kg}$ ), og blir eksponert for varicella, trenger sannsynligvis ikke VZIG hvis IVIG er gitt < 3 uker før eksponering (1). Vi har ikke funnet studier eller retningslinjer som omtaler beskyttende effekt av ukentlige subkutane injeksjoner med humant immunglobulin.

\section{Aktiv immunisering}

Aktiv immunisering med levende svekket varicellavaksine gir raskere immunrespons enn ved naturlige vannkopper. Det er derfor mulig at vaksinering etter eksponering kan indusere immunitet og modifisere det kliniske forløpet (르). En Cochrane-analyse fra 2008 konkluderer med at vaksine gitt til friske barn innen tre dager etter kontakt med smittede søsken, reduserer sykdomsrate og alvorlighetsgrad av sykdom (13). Konklusjonene bygger på tre små placebokontrollerte studier med til sammen 110 barn. Basert på inkubasjonstiden til varicella kan vaksinen tenkes å gi noe beskyttelse hvis den gis innen fem dager etter eksponering. Cochraneanalysen hadde for få inkluderte pasienter til å konkludere om vaksinen er effektiv hvis gitt etter dag 3 (13). Det er ikke utført studier på voksne. En høyere andel voksne responderer ikke på første dose av varicellavaksine, men vaksinen kan likevel tilbys voksne uten verifisert immunitet (1) . Vaksinering etter eksponering er først og fremst aktuelt hos personer med normalt immunforsvar 
uten kontraindikasjoner mot vaksinen. Hos slike personer er vaksinering å foretrekke fremfor passiv immunisering $(\underline{2}, \underline{14}$.). For pasienter med nedsatt immunforsvar er det en risiko for at vaksinen i seg selv kan gi infeksjon. Det er også usikkert om immunresponsen etter vaksinasjonen kan være suboptimal og dermed ikke gi nok beskyttelse (15).

Vaksinering av ikke-immune nærkontakter til immunkompromitterte kan redusere behovet for posteksponeringsprofylakse.

\section{Antiviral profylakse}

Vaksine er vanligvis kontraindisert hos pasienter der det er indikasjon for profylakse (ramme 1), og profylakse med VZIG gir ikke fullgod beskyttelse. Sammen med faktorer som tilgjengelighet, pris og det faktum at VZIG er et blodprodukt, gjør dette at man har behov for andre metoder for å forebygge varicella. Aciklovir benyttes i behandlingen av varicella og har vist effekt på utviklingen av komplikasjoner hos immunkompromitterte (1ㅡ). Aciklovir har også vært forsøkt som posteksponeringsprofylakse, enten alene eller i tillegg til VZIG. I tabell 1 oppsummeres studier eller kasuistikker som omhandler profylaktisk bruk av aciklovir for å forebygge varicellainfeksjon. Randomiserte placebokontrollerte studier er ikke utført. Tre kontrollerte studier er utført hos friske barn $(\underline{16})-(\underline{18})$. En randomisert kontrollert studie $(n=12)$, observasjonsstudier og kasuistikker beskriver posteksponeringsprofylakse med aciklovir hos immunkompromitterte, nyfødte og premature (19.)-(27). . Vi har ikke funnet studier som har unders $\emptyset$ kt effekten av antiviral profylakse hos voksne. De studiene vi har funnet er små og har flere metodologiske svakheter som gjør at resultatene må tolkes med forsiktighet. Immunkompromitterte som har fått aciklovirprofylakse etter eksponering, har i publiserte rapporter/studier i liten grad fått klinisk varicella (tab 1).

\section{Tabell 1}

Oppsummering av studier og kasusrapporter hvor aciklovir har vært benyttet som profylakse etter eksponering for varicella-zoster-virus

\begin{tabular}{|c|c|c|c|c|}
\hline \multirow[b]{2}{*}{ Referanse } & \multicolumn{4}{|c|}{$\begin{array}{l}\text { Starttidspunkt } \\
\text { Dosering/behandlingslengde etter }\end{array}$} \\
\hline & Studietype/Populasjon & aciklovir & eksponering & Resultat, antall syke \\
\hline $\begin{array}{l}\text { Goldstein } \\
\text { (19) }\end{array}$ & $\begin{array}{l}\text { Randomisert } \\
12 \text { barn (3-14 år) } \\
\text { Steroider pga. } \\
\text { nyresykdom }\end{array}$ & $\begin{array}{l}40 \mathrm{mg} / \mathrm{kg} / \mathrm{d} \varnothing g n \text { peroralt i } 4 \\
\text { doser (ev. dosereduksjon } \\
\text { ved nyresvikt). } \\
7 \text { dager. } \\
\text { I tillegg til VZIG (varicella- } \\
\text { zoster-immunglobulin) }\end{array}$ & 7 dager & $\begin{array}{l}\text { Behandlingsgruppe: } \\
0 \text { av } 8^{1} \\
\text { Kontrollgruppe } 2: \\
1 \text { av } 4^{1}\end{array}$ \\
\hline Asano (17) & $\begin{array}{l}\text { Ikke randomisert } \\
50 \text { friske barn ( } 4 \\
\text { md. }-9 \text { år) }\end{array}$ & $\begin{array}{l}40 \text { eller } 80 \mathrm{mg} / \mathrm{kg} / \mathrm{d} ø \mathrm{gn} \\
\text { peroralt i } 4 \text { doser. } \\
7 \text { dager }\end{array}$ & 7-9 dager & $\begin{array}{l}\text { Behandlingsgruppe: } \\
4 \text { av } 25 \text { (mild) } \\
\text { Kontrollgruppe: } \\
25 \text { av } 25\end{array}$ \\
\hline Suga (16) & $\begin{array}{l}\text { Ikke randomisert } \\
46 \text { friske barn (0,3-9 } \\
\text { år) }\end{array}$ & $\begin{array}{l}\text { Ca. } 40 \mathrm{mg} / \mathrm{kg} / \mathrm{d} \varnothing \mathrm{gn} \text { (doser } \\
\text { fra } 80-35 \mathrm{mg} / \mathrm{kg} / \mathrm{d} \varnothing \mathrm{gn}) \\
\text { peroralt i } 4 \text { doser. } \\
7 \text { dager }\end{array}$ & $\begin{array}{l}13 \text { barn: } 0-3 \\
\text { dager } \\
14 \text { barn: } 6-10 \\
\text { dager }\end{array}$ & $\begin{array}{l}\text { Behandlingsgruppe: } \\
\text { 0-3 dager: } 10 \text { av } 13 \\
\text { 6-10 dager: } 3 \text { av } 14 \\
\text { (mild) } \\
\text { Kontrollgruppe: } \\
19 \text { av } 19\end{array}$ \\
\hline Lin (18) & $\begin{array}{l}\text { Ikke randomisert } \\
40 \text { friske barn }\end{array}$ & $\begin{array}{l}40 \mathrm{mg} / \mathrm{kg} / \mathrm{d} \varnothing g n \text { peroralt i } 4 \\
\text { doser. } \\
5 \text { dager }\end{array}$ & $\begin{array}{l}17 \text { barn: } 9 \\
\text { dager } \\
10 \text { barn: } 11 \\
\text { dager }\end{array}$ & $\begin{array}{l}\text { Behandlingsgruppe: } \\
9 \text { dager: } 0 \text { av } 17 \\
11 \text { dager: } 2 \text { av } 10 \\
\text { Kontrollgruppe: } \\
10 \text { av } 13\end{array}$ \\
\hline
\end{tabular}




\begin{tabular}{|c|c|c|c|c|}
\hline \multirow[b]{2}{*}{ Referanse } & \multicolumn{4}{|c|}{$\begin{array}{l}\text { Starttidspunkt } \\
\text { Dosering/behandlingslengde etter }\end{array}$} \\
\hline & Studietype/Populasjon & aciklovir & eksponering & Resultat, antall syke \\
\hline $\begin{array}{l}\text { Shinjoh } \\
(23)\end{array}$ & $\begin{array}{l}\text { Observasjon } \\
169 \text { immunfriske og } \\
\text { immunsvekkede barn } \\
\text { på sykehus }^{3,4}\end{array}$ & $\begin{array}{l}40 \mathrm{mg} / \mathrm{kg} / \mathrm{d} ø g n \text { peroralt i } 4 \\
\text { doser,ev. } 5 \mathrm{mg} / \mathrm{kg} / \mathrm{dose} \text { i } 3 \\
\text { doser intravenøst. } \\
\text { Minimum } 7 \text { dager ev. } \\
\text { tillegg av IVIG (intravenøst } \\
\text { immunglobulin) }\end{array}$ & 7 dager & $\begin{array}{l}3 \text { av } 158 \\
\text { (mild) } \\
\text { Kontrollgruppe } \\
2 \text { av } 11\end{array}$ \\
\hline Huang (25) & $\begin{array}{l}\text { Observasjon } \\
10 \text { nyfødte, utslett } \\
\text { mor } 7 \text { dager før eller } \\
5 \text { dager etter fødsel }\end{array}$ & $\begin{array}{l}5 \mathrm{mg} / \mathrm{kg} \text { hver } 8 \text {. time } \\
\text { intravenøst i } 5 \text { dager alene } \\
\text { eller i tillegg til IVIG }\end{array}$ & $\begin{array}{l}7 \text { dager etter } \\
\text { start av mors } \\
\text { utslett }\end{array}$ & 0 av 10 \\
\hline $\begin{array}{l}\text { Sørensen } \\
(24)\end{array}$ & $\begin{array}{l}\text { Observasjon } \\
8 \text { barn med ALL } \\
\text { (akutt lymfoblastisk } \\
\text { leukemi) }\end{array}$ & $\begin{array}{l}40 \mathrm{mg} / \mathrm{kg} / \mathrm{d} \varnothing \mathrm{gn} \text { peroralt i } 4 \\
\text { doser. } \\
\text { 2-39 dager }\end{array}$ & $0-10$ dager & 3 av $8^{1}$ \\
\hline $\begin{array}{l}\text { Kumagai } \\
(20)\end{array}$ & $\begin{array}{l}\text { Observasjon } \\
13 \text { friske barn }\end{array}$ & $\begin{array}{l}40 \mathrm{mg} / \mathrm{kg} / \mathrm{d} \varnothing g n \text { peroralt i } 4 \\
\text { doser. } \\
7 \text { dager }\end{array}$ & 7 dager & $\begin{array}{l}2 \text { av } 13 \text { (mild) } \\
\text { Ett tilfelle vanskelig } \\
\text { klassifiserbart }\end{array}$ \\
\hline Ishida (21) & $\begin{array}{l}\text { Kasusrapport } \\
3 \text { barn med ALL }\end{array}$ & $\begin{array}{l}30 \text { eller } 40 \mathrm{mg} / \mathrm{kg} / \mathrm{d} \varnothing \mathrm{gn} \\
\text { peroralt i } 4 \text { doser i } 5-10 \\
\text { dager i tillegg IVIG (2 } \\
\text { pasienter) }\end{array}$ & 48 timer & $\begin{array}{l}2 \text { av } 3 \text { mild sykdom } \\
\text { utenfeber }\end{array}$ \\
\hline Hirose (22) & $\begin{array}{l}\text { Kasusrapport } \\
13 \text { år, SLE (systemisk } \\
\text { lupus } \\
\text { erythematosus), } \\
\text { immunsupprimert }\end{array}$ & $\begin{array}{l}4000 \mathrm{mg} / \mathrm{d} \varnothing \mathrm{gn} \text { peroralt i } 4 \\
\text { doser. } \\
7 \text { dager }\end{array}$ & 7 dager & $\begin{array}{l}\text { Syk (fatal) } 50 \text { dager } \\
\text { etterfamilieutbrudd }\end{array}$ \\
\hline $\begin{array}{l}\text { Hernández } \\
\text { (26) }\end{array}$ & $\begin{array}{l}\text { Kasusrapport } \\
2 \text { barn ( } 3 \text { og } 5 \text { år) } \\
\text { steroider pga. } \\
\text { nyresykdom }\end{array}$ & $\begin{array}{l}80 \mathrm{mg} / \mathrm{kg} / \mathrm{d} ø g n \text { i } 4 \text { doser. } \\
5 \text { dager. }\end{array}$ & 9 dager & 0 av 2 \\
\hline \multirow{2}{*}{$\begin{array}{l}\text { Hayakawa } \\
(27)\end{array}$} & $\begin{array}{l}\text { Kasusrapport } \\
35 \text { uker gammelt } \\
\text { barn eksponering av } \\
\text { mor. }\end{array}$ & $\begin{array}{l}15 \mathrm{mg} / \mathrm{kg} / \mathrm{d} \varnothing \mathrm{gn} \text { intravenøst } \\
\text { i } 3 \text { doser. } \\
7 \text { dager }\end{array}$ & 7 dager & $\begin{array}{l}\text { Syk } 37 \text { dager etter } \\
\text { eksponering }\end{array}$ \\
\hline & $\begin{array}{l}\text { Kasusrapport } \\
6 \text { premature barn } \\
\text { født før uke } 34 .\end{array}$ & $\begin{array}{l}40 \mathrm{mg} / \mathrm{kg} / \mathrm{d} \varnothing \mathrm{gn} \text { peroralt i } 4 \\
\text { doser. } \\
7 \text { dager }\end{array}$ & 7 dager & 0 av 6 \\
\hline
\end{tabular}

[i] ${ }^{1}$ Enkelte barn eksponert flere ganger

${ }^{2}$ Kontrollgruppen fikk kun VZIG (varicella-zoster-immunglobulin)

${ }^{3}$ Pasienter med tidligere varicella samt vaksinering ble inkludert

${ }^{4}$ Barn innlagt i samme avdeling ved utbruddet ble regnet som eksponert

${ }^{5}$ Kontrollgruppen besto kun av immunfriske 
Aciklovir gitt i tillegg til VZIG har vært forsøkt i en mindre randomisert kontrollert studie hos barn med steroidkrevende nyresykdom (19.). Åtte pasienter (ti eksponeringer) fikk aciklovir fra dag $7 \mathrm{i}$ tillegg til VZIG gitt før 96 timer. Hos en pasient var det tegn på subklinisk varicella. En av fire pasienter (seks eksponeringer) som fikk VZIG alene, fikk klinisk varicella. Studien er for liten til å trekke konklusjoner. Det er behov for flere studier hos risikopasienter der man undersøker effekten av aciklovir, alene eller sammen med VZIG, mot VZIG.

På tross av svak dokumentasjon mener vi at aciklovir/valaciklovir bør gis som profylakse til pasienter hvor VZIG er indisert, men der man er for sent ute til å forvente effekt av VZIG. Vi mener aciklovir/valaciklovir også bør vurderes gitt i tillegg til VZIG hos pasienter der det er sett høy dødelighet av varicella, f.eks. etter beinmargstransplantasjon. Norsk barnelegeforening anbefaler i sin Veileder i generell pediatri, at det gis antiviral profylakse etter eksponering av

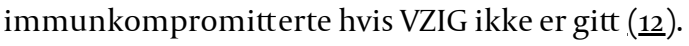

Den doseringen som er brukt i flest studier er aciklovir $40 \mathrm{mg} / \mathrm{kg} / \mathrm{d} ø$ gn i fire doser (tab1). Det kan virke som profylakse med aciklovir i siste halvdel av inkubasjonsperioden (7-14 dager etter

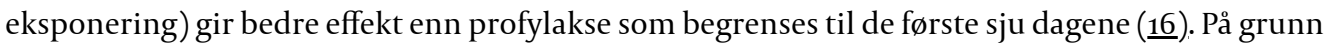
av hyppig dosering av aciklovir kan det være vanskelig å huske å ta alle tablettene. Valaciklovir (Valtrex) er et mulig alternativ. Valaciklovir omdannes i kroppen til aciklovir, og oral biotilgjengelighet er 3-5 ganger større enn for aciklovir, noe som gjør at det kan doseres sjeldnere $(\underline{28})$. Valaciklovir er godkjent til behandling av varicella hos immunkompetente barn over to år i USA, men ikke i Norge $(\underline{\mathbf{2}}, \underline{2} \mathbf{2}$.). Norsk barnelegeforening anbefaler peroral aciklovir $10 \mathrm{mg} / \mathrm{kg} \times 5$ eller valaciklovir $10 \mathrm{mg} / \mathrm{kg} \times 2(\underline{\mathbf{1 2}})$.

Optimal lengde på profylaktisk behandling er ikke undersøkt. De studier og kasuistikker vi har funnet, har profylaksevarighet på 5-10 dager (tab 1). Det er ikke kjent om en lengre profylakse er nødvendig hos immunsupprimerte, men det kan ikke utelukkes (22). Et senter i USA beskriver bruk av valaciklovir eller aciklovir på post-eksponeringsdag 3-22 (3-28 hvis VZIG også er gitt) hos beinmargstransplanterte pasienter, men har ikke angitt hvor mange de har behandlet med dette regimet eller om det er effektivt (3ô). I en oppsummering av et dansk materiale ble peroral aciklovirprofylakse gitt etter varicellaeksponering hos åtte barn (15 eksponeringer) med akutt lymfoblastisk leukemi. Innføring av profylakse i 5-7 dager med start 7-10 dager etter eksponering, ga tilsynelatende ingen endring i varicellarisiko (en av seks eksponeringer endte med varicella), sammenliknet med pasienter som fikk aciklovir 2-39 dager med start o-6 dager etter eksponering (to av ni eksponeringer ga varicella) (24).). Materialet er for lite til å trekke konklusjoner. Norsk barnelegeforening anbefaler en profylaksevarighet på 14 dager fra dag $7(\underline{12})$.

Det er viktig å sjekke immunstatus etter profylakse for å undersøke om pasienten trenger

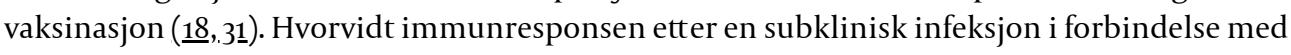
aciklovirprofylakse er nok til å beskytte mot senere infeksjoner og utvikling av zoster, er ikke godt nok studert. Små observasjonsstudier tyder på at immuniteten holder seg i alle fall i 2 1/2-3 år hos

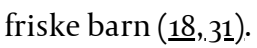

Den vanligste bivirkningen av aciklovir er utslett, som oppstår hos cirka $3 \%$ av pasientene. Andre bivirkninger er tretthet, hodepine, svimmelhet og gastrointestinale bivirkninger (32). Aciklovir elimineres renalt og kan gi redusert nyrefunksjon, særlig hos dehydrerte pasienter. Risikoen reduseres ved å følge doseringsangivelsene og hydrere pasientene (33). I en observasjonsstudie med 169 hospitaliserte barn (hvorav 79 var immunkompromitterte), fikk 158 pasienter aciklovir som posteksponeringsprofylakse etter eksponering for varicella-zoster-virus. Forfatterne angir at det ikke ble observert bivirkninger av aciklovir, men metode for bivirkningsregistrering er ikke rapportert (23).

\section{Konklusjon}

Det er lite og svak dokumentasjon for at profylaktiske tiltak etter eksponering for varicella-zostervirus reduserer risiko for varicella og sykdommens alvorlighetsgrad. I mangel på god dokumentasjon må man støtte seg til de få studiene som finnes. Vaksine gitt til friske barn innen tre dager etter eksponering er vist å redusere sykdomsrate og alvorlighetsgrad. Passiv immunisering med VZIG er indisert som posteksponeringsprofylakse hos risikopasienter, og det er noe dokumentasjon for at VZIG reduserer risiko for alvorlig forløp av varicella. Klinisk varicella på tross av VZIG-profylakse er imidlertid vanlig. Profylaktisk aciklovir er undersøkt i små studier, hovedsakelig på friske barn, men effekt, dosering, starttidspunkt og lengden av profylaksen er ikke 
tilstrekkelig dokumentert. Fordi varicella hos immunkompromitterte kan være alvorlig, mener vi profylakse med aciklovir eller valaciklovir bør benyttes når man er for sent ute med VZIG. Svært lite dokumentasjon foreligger for kombinasjonen av aciklovir og VZIG, men dette kan være aktuelt i spesielle tilfeller.

\section{LITTERATUR}

1. Marin M, Güris D, Chaves SS et al. Prevention of varicella: recommendations of the Advisory Committee on Immunization Practices (ACIP). MMWR Recomm Rep 2007; 5 6 (RR-4):1-40. [PubMed]

2. Ogilvie MM. Antiviral prophylaxis and treatment in chickenpox. A review prepared for the UK Advisory Group on Chickenpox on behalf of the British Society for the Study of Infection. J Infect 1998;36 (suppl 1):31-8. [PubMed] [CrossRef]

3. Swingler G. Chickenpox. Clin Evid (Online) 2007; 12: pii 912.

4. Zaia JA, Levin MJ, Preblud SR et al. Evaluation of varicella-zoster immune globulin: protection of immunosuppressed children after household exposure to varicella. J Infect Dis 1983; 147: 737-43. [PubMed] [CrossRef]

5. Orenstein WA, Heymann DL, Ellis RJ et al. Prophylaxis of varicella in high-risk children: dose-response effect of zoster immune globulin. J Pediatr 1981; 98:368-73. [PubMed] [CrossRef]

6. Brunell PA, Ross A, Miller LH et al. Prevention of varicella by zoster immune globulin. N Engl J Med 1969; 280: 1191-4. [PubMed] [CrossRef]

7. Meyers JD. Congenital varicella in term infants: risk reconsidered. J Infect Dis 1974; 129: 215-7. [PubMed] [CrossRef]

8. Tebruegge M, Pantazidou A, Curtis N. Towards evidence based medicine for paediatricians. How effective is varicella-zoster immunoglobulin (VZIG) in preventing chickenpox in neonates following perinatal exposure? Arch Dis Child 2009; 94: 559-61. [PubMed] [CrossRef]

9. Folkehelseinstituttet. Vaksinasjonshåndboken. Varicellavaksine (vannkopper) og immunglobulin mot vannkopper. www.fhi.no/artikler/?id=68714 (25.3.2009).

10. Stray-Pedersen B, Sørbye IK, Sviggum O et al. Kapittel 12.4 - Varicella. I: Veileder i fødselshjelp. Oslo: Norsk gynekologisk forening, 2008. www.legeforeningen.no/id/131715.0 (2.7.2010).

11. Albrecht MA. Treatment of varicella-zoster virus infection: chickenpox. I: UpToDate, Hirsch MS (section ed). www.uptodate.com/(6.10.2009).

12. Nøkleby H, Klingenberg C. 3.16 vaksiner og immunprofylakse. I: Veileder i generell pediatri. Oslo: Norsk barnelegeforening, 2009. www.barnelegeforeningen.no (18.8.2009).

13. Macartney K, McIntyre P. Vaccines for post-exposure prophylaxis against varicella (chickenpox) in children and adults. Cochrane Database Syst Rev 2008; nr. 3: CDoo1833. [PubMed]

14. Hambleton S, Gershon AA. Preventing varicella-zoster disease. Clin Microbiol Rev 2005; 18: 70-80. [PubMed] [CrossRef]

15. Levin MJ. Varicella vaccination of immunocompromised children. J Infect Dis 2008; 197 (suppl 2): S20o-6. [PubMed] [CrossRef]

16. Suga S, Yoshikawa T, Ozaki T et al. Effect of oral acyclovir against primary and secondary viraemia in incubation period of varicella. Arch Dis Child 1993; 69: 639-43. [PubMed] [CrossRef]

17. Asano Y, Yoshikawa T, Suga S et al. Postexposure prophylaxis of varicella in family contact by oral acyclovir. Pediatrics 1993; 92: 219-22. [PubMed]

18. Lin TY, Huang YC, Ning HC et al. Oral acyclovir prophylaxis of varicella after intimate contact. Pediatr Infect Dis ] 1997; 16: 1162-5. [PubMed] [CrossRef]

19. Goldstein SL, Somers MJ, Lande MB et al. Acyclovir prophylaxis of varicella in children with renal disease receiving steroids. Pediatr Nephrol 2000; 14:305-8. [PubMed] [CrossRef]

20. Kumagai T, Kamada M, Igarashi $C$ et al. Varicella-zoster virus-specific cellular immunity in subjects given acyclovir after household chickenpox exposure. J Infect Dis 1999; 180: 834-7. [PubMed] [CrossRef]

21. Ishida Y, Tauchi H, Higaki A et al. Postexposure prophylaxis of varicella in children with leukemia by oral acyclovir. Pediatrics 1996; 97: 150-1. [PubMed]

22. Hirose I, Ymamaguchi H, Inaguma D et al. Fatal varicella infection in a girl with systemic lupus erythematosus after oral acyclovir prophylaxis. Eur J Pediatr 2006; 165: 280-1. [PubMed] [CrossRef]

23. Shinjoh M, Takahashi T. Varicella zoster exposure on paediatric wards between 2000 and 2007: safe and effective post-exposure prophylaxis with oral aciclovir. J Hosp Infect 2009; 72: 163-8. [PubMed] [CrossRef] 
24. Sørensen GV, Helgestad J, Rosthøj S. Varicel-associeret morbiditet hos børn i kemoterapi for akut lymfoblastaer leukaemi. Ugeskr Læger 2009; 171:3354-9. [PubMed]

25. Huang YC, Lin TY, Lin YJ et al. Prophylaxis of intravenous immunoglobulin and acyclovir in perinatal varicella. Eur J Pediatr 2001; 160: 91-4. [PubMed] [CrossRef]

26. Martín Hernández E. Acyclovir prophylaxis of varicella in children with nephrotic syndrome. Pediatr Nephrol 200o; 15:326-7. [PubMed]

27. Hayakawa M, Kimura H, Ohshiro M et al. Varicella exposure in a neonatal medical centre: successful prophylaxis with oral acyclovir. J Hosp Infect 2003; 54: 212-5. [PubMed] [CrossRef]

28. Statens legemiddelverk. Preparatomtale (SPC) Valtrex. www.legemiddelverket.no/legemiddelsok (sist endret 15.6.2010).

29. Lexi-Comp Online database. Valtrex. www.helsebiblioteket.no/ (2.7.2010).

30. Weinstock DM, Boeckh M, Sepkowitz KA. Postexposure prophylaxis against varicella zoster virus infection among hematopoietic stem cell transplant recipients. Biol Blood Marrow Transplant 2006; 12: 1096-7. [PubMed] [CrossRef]

31. Yoshikawa T, Suga S, Kozawa T et al. Persistence of protective immunity after postexposure prophylaxis of varicella with oral aciclovir in the family setting. Arch Dis Child 1998; 78: 61-3. [PubMed] [CrossRef]

32. Statens legemiddelverk. Preparatomtale (SPC) Zovirax. www.legemiddelverket.no/legemiddelsok (sist endret 2.2.2009).

33. Norsk legemiddelhåndbok for helsepersonell. L1.4.4.1 Aciklovir/valaciklovir. www.legemiddelhandboka.no/(1.4.2009).

Publisert: 6. september 2011. Tidsskr Nor Legeforen. DOI: 10.4045/tidsskr.10.0149

Mottatt 3.2. 2010, første revisjon innsendt 14.7. 2010, godkjent 16.6. 2011. Medisinsk redaktør Trine B. Haugen.

(C) Tidsskrift for Den norske legeforening 2023. Lastet ned fra tidsskriftet.no 26. april 2023. 